\title{
Sports in Children's Picture Books
}

\author{
Aynur Yilmaz ${ }^{1, *}$, Şengül Pala ${ }^{2}$ \\ ${ }^{1}$ Faculty of Sport Science, Trabzon University, Turkey \\ ${ }^{2}$ Faculty of Education, Kirikkale University, Turkey
}

Copyright $\bigcirc 2019$ by authors, all rights reserved. Authors agree that this article remains permanently open access under the terms of the Creative Commons Attribution License 4.0 International License

\begin{abstract}
From an early age, it is very important to encourage children to enjoy sports and to make sports. The awareness and habits gained in the early years of life affect life in the following years. Illustrated children's books are important for early childhood children to gain interest, curiosity and awareness towards an area. Sports and sports-specific elements are among the habits that should be given to children at a young age. The aim of this study is to determine the sport elements in the children's books. For this purpose, the research was designed with a case study pattern of qualitative research approaches. Criterion sampling technique was used in the study. Thirty books with 3-6 years old child development characteristics and the subject of which are direct sports are included in the study group. Document analysis technique was used in data analysis. In the research, it has been determined that books related to different sports branches, sports materials are depicted, sports-specific concepts are mentioned and technical and tactical information is presented. In the sections where sporting competitions take place, are depicted such as fairness / fair competition, fairness, benevolence and ability to tolerate winning-loss values. The processing of sports in illustrated children's books will be effective in the positive attitudes of children in this age of development towards sports.
\end{abstract}

Keywords Sport, Illustrated Children's Books, Sports Environment, Gender, Document Analysis

\section{Introduction}

Nowadays, rapidly developing technology and living conditions have pushed individuals to live faster. Individuals who act with the goal of doing much work in less time and attaining more products have started to pursue this goal in many areas of their lives with or without the awareness of this goal. This goal has caused stress and pressure on individuals. In addition, this situation has led individuals to commute to their works in a vehicle rather than walking to arrive faster and to consume foods that can be quickly eaten at their lunch breaks so that they can go back to their work earlier. All these have reduced the quality of people's lives and imposed a sedentary living culture on people.

As it is not possible to remove this fast lifestyle completely from the life of people, it has become necessary for them to make a series of activities in order to protect their physical and psychological health and to lead a better quality life. Sports is the leading one among these activities because sports is a set of activities that meet the people' need to move, entertain and socialize [1]. Moreover, sports is also an activity that promotes cognitive, social and emotional development of individuals, improves their problem-solving skills, supports concept development and increases their physical awareness [2-3-4]. On the other hand, the love of sports developed at early ages (pre-school period) is of great importance for gaining the habit of doing sports [5].

Today, children tend to spend their free time more passively (e.g. watching television, playing computer games) [6]. Thus, before they even become aware of their bodies, feel the need for participating in any kind of physical activity, children internalize the elements of virtual sports, leading the creation of obese and asocial generations [7]. Research has shown that the basics of interest in sports in adulthood are related to childhood sports activities. Because many positive behaviors, attitudes and habits in people's lives are rooted in experiences lived in pre-school period [8]. The foundation of sports habits is formed by the activities carried out in pre-school education institutions and the learning opportunities offered to children in this period [9]. According to [10], for children directed to sports at early ages, sport is a basic need like eating and sleeping. Children who develop basic movement skills will be ready to develop specialized skills and transfer these skills to recreational, play, sport and dance activities. For all these to be accomplished, learning opportunities and stimuli offered to children in compliance with their developmental level are quite effective. Children's picture books are one of these stimuli.

Children need books to expand their horizons, deepen 
their understanding and improve their social conception. As a part of their environment, the first books they are introduced to are picture books and they have a huge impact on the child's whole development, and when they are well organized and expressed, they highlight the beauty of expression through pictures and words. Besides stimulating the preschooler through words and pictures, picture books can promote their development or even encourage them to acquire critical consciousness [11]. Via qualified children's books, children begin to develop interest in and awareness of many subjects. Through picture books with the theme of sports, children learn many sports branches which help them discover new areas of interest to them. Their learning many sports-related concepts and terms contribute to the development of their vocabulary. Each new sport branch and concept they have learned increases their interest in sports and enables them to discover new areas that are relevant to their interests. Thanks to this growing interest, they love sports and feel more motivated to do sports.

Although it is thought that the development of psychomotor skills in the education process can be more supported through activities that involve physical activity, it is known that children's picture books in which examples of physical activities are depicted can contribute to the development of these skills [12]. In addition, children have the opportunity to embody the information they have acquired through the pictures in the book. All these elements raise children's interest in and love for sports. Children who love sports and are interested in different sports branches are willing to do sports. This willingness is important in terms of gaining the habit of doing sports.

For this reason, it is important to examine children's picture books occupying an important place in children's lives in terms of sports and sports related elements (sports branch, sports materials, sports environments, people involved in sports environments, sports-specific concepts and sports-specific values). When the research conducted on the concept of sports [13-3-4-9-14] is examined, it is seen that different sub-categories have been elicited such as sports branches, sports-specific values, sports materials. The purpose of the current study is to examine the sports elements in children's picture books with the theme of sports. To this end, answers to the following questions were sought.

- What are the sports branches depicted in children's picture books?

- What are the sports materials specific to the sports branches depicted in children's picture books?

- What are the technical terms specific to the sports branches depicted in children's picture books?

- What are the sports-specific values depicted in children's picture books?

- What are the genders of the heroes in children's picture books?
- What are the sports-related terms and visuals found in children's picture books?

- What is the gender distribution of the writers of the children's picture books?

\section{Materials and Methods}

\subsection{Research Model}

In order to determine the sports elements in children's picture books, the document analysis technique, one of the qualitative research methods, was employed. This analysis technique involves the analysis of written materials having information about the target phenomenon or phenomena [15]. The current study aimed to determine the sports elements found in 3-6 year-old children's picture books maximum of three levels of headings may be used.

\subsection{Study Group}

In the selection of the study group, the criterion sampling method; one of the purposive sampling methods allowing the in-depth analysis of the cases thought to include rich data, was used [16-17-18]. While determining the documents to be included in the study group, children's picture books were examined and it was found that the picture books with the theme of sports were very limited before 2010. Therefore, the children's picture books published in the last seven years with the theme of sports were included in the study group. The criteria adopted in the selection of these books were their being in compliance with the developmental characteristics of 3-6 year olds and their having the theme of sports. On the basis of these criteria, a total of 75 books were selected from among the 3-6 year old children's literature. As in 40 of these books no sports-related elements were found and in 4 of them very few sports-related elements were found, they were discarded from the analysis. Thus, the analyses of the current study were conducted on a total of 30 books. The distribution of the examined children's picture books across the publishing houses is given in Table 1:

Table 1. Distribution of the examined children's picture books across the publishing houses

\begin{tabular}{lll}
\hline Publishing house & F & $\%$ \\
\hline Türkiye İş Bankası Publishing & 16 & 53,3 \\
\hline Yapı Kredi Publishing & 7 & 23,3 \\
\hline Mavi Kelebek Publishing & 1 & 3,3 \\
\hline Epsilon Publishing & 1 & 3,3 \\
\hline Marsik Books & 1 & 3,3 \\
\hline Tubitak Publishing & 1 & 3,3 \\
\hline Abm Publishing & 1 & 3,3 \\
\hline Mavi Bulut Publishing & 1 & 3,3 \\
\hline 1001 Çiçek Books & 1 & 3,3 \\
\hline Total & 30 & 100 \\
\hline
\end{tabular}


As can be seen in Table 1, the children's picture books including the highest number of sports elements have been published by Türkiye İş Bankası Publishing and Yapı Kredi Publishing. Thus, it can be argued that some certain publishing houses support the publishing of certain types of books.

As can be seen in Table 2, the distribution of the children's picture books across the years of publishing is as follows: in $2010(\mathrm{f}=1)$, in $2011(\mathrm{f}=3)$, in $2012(\mathrm{f}=1)$, in $2013(\mathrm{n}=2)$, in $2014(\mathrm{n}=3)$, in $2016(\mathrm{f}=3)$, in $2017(\mathrm{f}=8)$ and in 2018 ( $\mathrm{f}=9$ ) thus, a total of 30 children's picture books were included in the current study. The increasing number of books over time indicates that more importance is attached to sports in picture's books in recent years.

Table 2. The names of the examined children's picture books and their distribution across the years of publishing

\begin{tabular}{|c|c|c|c|c|c|}
\hline Year of publishing & Book name & Writer/Country & Code & $\mathrm{f}$ & $\%$ \\
\hline 2010 & $\begin{array}{l}\text { **Sihirli Top } \\
\text { Magic Ball (Turkish) }\end{array}$ & Fatih Erdoğan/Turkey & $* * \mathrm{~K} 1$ & 1 & 3,3 \\
\hline \multirow{3}{*}{2011} & *Ayşegül is riding a horse & Gilbert Delahaye/Hamburg & $* * \mathrm{~K} 2$ & \multirow{3}{*}{3} & \multirow{3}{*}{10,0} \\
\hline & *Elif is in the sea & Liane Schneider/Hamburg & $* * \mathrm{~K} 21$ & & \\
\hline & *Ayşegül is doing ballet & Gilbert Delahaye/Hamburg & $* * \mathrm{~K} 3$ & & \\
\hline 2012 & *Wriggly & Ann Bonwil & $* * \mathrm{~K} 4$ & 1 & 3,3 \\
\hline \multirow{2}{*}{2013} & $\begin{array}{l}* \text { Ich hab eine Freundin, die ist Balletttänzerin } \\
\text { My friend is a ballerina }\end{array}$ & Ralf Butschkow/Germany & $* * \mathrm{~K} 22$ & \multirow{2}{*}{2} & \multirow{2}{*}{6,6} \\
\hline & $\begin{array}{l}\text { *Ich hab einen Freund, der ist Rennfahrer } \\
\text { My friend is a racing driver }\end{array}$ & Ralf Butschkow/Germany & $* * \mathrm{~K} 23$ & & \\
\hline \multirow{3}{*}{2014} & $\begin{array}{l}\text { *Win haben einen Freund, der ist FuBballspieler } \\
\text { My friend is a professional footballer }\end{array}$ & Ralf Butschkow/Germany & $* * \mathrm{~K} 5$ & \multirow{3}{*}{3} & \multirow{3}{*}{10,0} \\
\hline & *Maisy lerns to swim & Lucy Cousins/London & $* * \mathrm{~K} 24$ & & \\
\hline & *Ayşegül is enjoying the sea & Gilbert Delahaye/ & $* * \mathrm{~K} 25$ & & \\
\hline \multirow{3}{*}{2016} & *Franklin rides a bike & Paulette Bourgeois/Canada & **K6 & \multirow{3}{*}{3} & \multirow{3}{*}{10,0} \\
\hline & $\begin{array}{l}\text { *Wir machen Sport } \\
\text { We are doing sports }\end{array}$ & Sandra Ladwig/Hamburg & $* * \mathrm{~K} 12$ & & \\
\hline & *Elif and her favorite pony & Liana Schneider/Germany & $* * \mathrm{~K} 20$ & & \\
\hline \multirow{8}{*}{2017} & $\begin{array}{l}\text { *Jule traut sich!-Ein Mutmach-Buch } \\
\text { İnci is very brave (swimming) }\end{array}$ & Anna Wagenhoff/Germany & $* * \mathrm{~K} 7$ & \multirow{8}{*}{8} & \multirow{8}{*}{26,6} \\
\hline & $\begin{array}{l}\text { *Conni lernt Rad fahren (Original) } \\
\text { Elif is learning riding a bike }\end{array}$ & Liane Schneider/Hamburg & $* * \mathrm{~K} 8$ & & \\
\hline & $\begin{array}{l}* * \text { Yogayı seviyorum } \\
\text { I love yoga (Turkish) }\end{array}$ & Ezgi Berk/Turkey & $* * \mathrm{~K} 9$ & & \\
\hline & $\begin{array}{l}\text { *Tu pots (Original) } \\
\text { I can do it (Basketball) }\end{array}$ & Jennifer Moore-Mallions/Spain & $* * \mathrm{~K} 10$ & & \\
\hline & *I am ready, I can do it, You can do it, We can do it & Jennifer Moore-Mallinos & $* * \mathrm{~K} 11$ & & \\
\hline & *My friend is a footballer & - & $* * \mathrm{~K} 13$ & & \\
\hline & $\begin{array}{l}\text { *Max wird Weltmeister (Original) } \\
\text { Çağlar is a world champion }\end{array}$ & Christian Tielmann/Hamburg & $* * \mathrm{~K} 14$ & & \\
\hline & *Ayşegül is skiing & Gilbert Delahaye/Hamburg & $* * \mathrm{~K} 28$ & & \\
\hline \multirow{9}{*}{2018} & $\begin{array}{l}{ }^{*} \text { Conni spielt FutBall (Original) } \\
\text { Elif is playing football }\end{array}$ & Liana Schneider/Germany & $* * \mathrm{~K} 15$ & \multirow{9}{*}{9} & \multirow{9}{*}{30,0} \\
\hline & $\begin{array}{l}{ }^{*} \text { Conni fahrt Ski (Original) } \\
\text { Elif is learning skiing }\end{array}$ & Liana Schneider/Germany & $* * \mathrm{~K} 16$ & & \\
\hline & $\begin{array}{l}\text { *Max lernt Rad fahren (Original) } \\
\text { Çağlar is learning riding a bike }\end{array}$ & Christian Tielmann/Germany & $* * \mathrm{~K} 17$ & & \\
\hline & *Elif is learning riding a horse & Liana Scneider/Germany & $* * \mathrm{~K} 18$ & & \\
\hline & *Elif is learning swimming & Liana Scneider/Germany & $* * \mathrm{~K} 19$ & & \\
\hline & *Ayşegül is learning swimming & Gilbert Delahaye/Hamburg & $* * \mathrm{~K} 26$ & & \\
\hline & *Ayşegül is sailing & Gilbert Delahaye/Hamburg & $* * \mathrm{~K} 27$ & & \\
\hline & *Ayşegül is learning riding a bike & Gilbert Delahaye/Hamburg & $* * \mathrm{~K} 29$ & & \\
\hline & $\begin{array}{l}\text { *Max lernt schwimmen (Original) } \\
\text { Çağlar is learning swimming }\end{array}$ & Christian Tielmann/Hamburg & $* * \mathrm{~K} 30$ & & \\
\hline Total & & & & 30 & 100 \\
\hline
\end{tabular}

*Books translated into Turkish. **Turkish books are coded in the study. 
Table 3. Investigation Criteria of the Sports Elements in Children's Picture Books

\begin{tabular}{ll}
\hline Sports Elements & Indicators (Verbal and Visual) \\
\hline Sports branch & Football/basketball/swimming/cycling etc. \\
\hline Sports branch-specific materials & Ball/bike/crash helmet/uniform/goal etc. \\
\hline Sports environment where the sports is done & Basketball court/football pitch/pool etc. \\
\hline People involved in the sports environment & Athlete/coach/referee/woman, man etc. \\
\hline Sports-specific concepts & Training/competition/rival/barrier/cup \\
\hline Sports-specific values & Winning/losing/competition/fair competition/friendship \\
\hline *[4-9-14] &
\end{tabular}

\subsection{Data Analysis}

In the current study the document analysis technique; one of the qualitative research methods, was used to investigate the elements of sports in children's books published in Turkey. In the document analysis, what is intended is to elicit the existing situation as it is on the basis of documents. Document analyses primarily rely on the scanning of the target document [19]. Document analysis occurs at four stages that are "the selection of the sample from the data source of interest, the development of categories, the determination of the unit of analysis and the digitization" [20]. Depending on the purpose of the study, the researcher can use different units of analysis such as "word, theme, character, sentence/paragraph and item/content". In the current study, "sentences" and "visuals" were used as the units of analysis in the investigation of the sports elements found in the children's picture books. In the current study, the sports elements found in the children's picture books (Table 3) were investigated in terms of the "visual and verbal" elements found in each book. While determining the criteria of investigation, the related literature was taken into consideration. Consecutively according to its appearance in the text. Cite each table in numerical order.

Before initiating the analysis of the data, pictures and texts in the children's picture books to be included in the unit of analysis were revised in terms of sports-specific elements and the books not including sports-specific statements and pictures were excluded from the analysis. The books in the study group were numbered, their pictures and texts were examined and it was decided under which themes the analysis would be conducted. These themes are sports branch, sports-specific materials, place/environment where the sports is done, people involved in the sports, sports-specific values and gender. When the books whose only theme is sports were examined, it was found that two books are about only the rules of football, two books are about cycling, two of them are about ballet and the themes of other books are horse riding, basketball, swimming, yoga and athletics.

\subsection{Data Processing and Analysis}

Each of 30 books in the study group was read by the researchers and each of the sports elements found in the books was classified as visual and verbal. In making sense of the pictures, sentences were drawn on. Rather than frequencies, diversity of the visual and verbal sports elements (concept, materials, sports environment, hero etc.) was taken into consideration. The analyses were conducted on the basis of diversity.

\subsection{Reliability and Validity of the Study}

In order to increase the internal reliability of the study, each book in the study group was examined twice by the researchers in the period between March and May 2018. In this way, it was aimed to reduce the impact stemming from some objective biases of the books (data sources) and of the researchers [19]. There are several techniques to provide information about whether a content analysis is reliable or not. Within the current study, the same documents were given to different researchers at different time intervals for them to code the children's picture books. The reliability of the content analysis conducted in the current study is closely associated with the execution of the coding operation. Precise identification and definition of the categories to be used in the content analysis is the most important stage of any content analysis. Thus, the reliability of the analysis increases and the objectivity of the study can be protected [18]. Two books were randomly selected from among the 30 books making up the study group of the current research and each of them was coded by the researcher and an expert on the basis of their inclusion of visual and verbal sports-specific elements. Then, in order to determine inter-rater reliability, the formula proposed by [21] was used. This formula is as follows: Reliability $=($ Number of Agreements $/$ Number of Agreements + Number of Disagreements $) \times 100$ Huberman (1994), if the inter-rater agreement is $70 \%$ or higher, then it is considered to be acceptable [18]. In the current study, it was calculated to be 0.94 .

\section{Results}

In this section of the study, visual and verbal sports-specific elements found in the children's picture books are given. One of the sports-specific elements in the children's picture books is sports branches and the findings related to this element are presented in Table 4 . 
Table 4. Sports Branches Depicted in the Children's Picture Books

\begin{tabular}{|c|c|c|}
\hline & Book Name & Sports branches depicted in the book \\
\hline *K1 & Magic Ball & Football \\
\hline$* * \mathrm{~K} 2$ & Ayşegül is riding a horse & Horse riding \\
\hline$* * \mathrm{~K} 3$ & Ayşegül is doing ballet & Ballet \\
\hline$* * \mathrm{~K} 4$ & Wriggly & Ballet \\
\hline$* * \mathrm{~K} 5$ & My friend is a professional footballer & Football, Cycling \\
\hline$* * \mathrm{~K} 6$ & Franklin is riding a bike & Cycling, Swimming, Baseball, Skating \\
\hline **K12 & We are doing sports & $\begin{array}{l}\text { Gymnastics, Football, Ballet, Judo, } \\
\text { Yoga, Swimming, Horse Riding, Skiing, Cycling }\end{array}$ \\
\hline$* * \mathrm{~K} 7$ & İnci is very brave & Swimming, Cycling \\
\hline$* * \mathrm{~K} 8$ & Elif is learning riding a bike & Cycling \\
\hline$* * \mathrm{~K} 9$ & I love yoga & Yoga \\
\hline$* * \mathrm{~K} 10$ & I can do it & Basketball \\
\hline$* * \mathrm{~K} 11$ & I am ready, I can do it, You can do it, We can do it & Athletics, Archery, Running \\
\hline$* * \mathrm{~K} 13$ & My friend is a footballer & Football \\
\hline$* * \mathrm{~K} 14$ & Çağlar is a world champion & Football \\
\hline$* * \mathrm{~K} 15$ & Elif is playing football & Football, Bicycle \\
\hline$* * \mathrm{~K} 16$ & Elif is learning skiing & Ski \\
\hline$* * \mathrm{~K} 17$ & Çağlar is learning riding a bike & Bicycle \\
\hline$* * \mathrm{~K} 18$ & Elif is learning riding a horse & Horse riding \\
\hline$* * \mathrm{~K} 19$ & Elif is learning swimming & Swimming \\
\hline$* * \mathrm{~K} 20$ & Elif and her favorite pony & Horse riding \\
\hline$* * \mathrm{~K} 21$ & Elif is in the sea & Swimming \\
\hline$* * \mathrm{~K} 22$ & My friend is a ballerina & Ballet \\
\hline$* * \mathrm{~K} 23$ & My friend is a racing driver & Motor racing \\
\hline$* * \mathrm{~K} 24$ & Maisy is learning swimming & Swimming \\
\hline$* * \mathrm{~K} 25$ & Ayşegül is enjoying the sea & Swimming \\
\hline$* * \mathrm{~K} 26$ & Ayşegül is learning swimming & Swimming \\
\hline$* * \mathrm{~K} 27$ & Ayşegül is sailing & Sail, Swimming \\
\hline$* * \mathrm{~K} 28$ & Ayşegül is skiing & Ski \\
\hline$* * \mathrm{~K} 29$ & Ayşegül is learning riding a bike & Bicycle \\
\hline$* * \mathrm{~K} 30$ & Çağlar is learning swimming & Swimming \\
\hline
\end{tabular}

As can be seen in Tablo 4, the sports branches in the analyzed books were found to be "cycling", "football", "yoga", "horse riding", "ballet", "swimming", "basketball", "dance", "fishing", "baseball", "athletics", "archery", "care racing", "skiing", "sailing" and "judo". The branch of swimming was found to be most depicted in the children's picture books. This is followed by football, athletics.

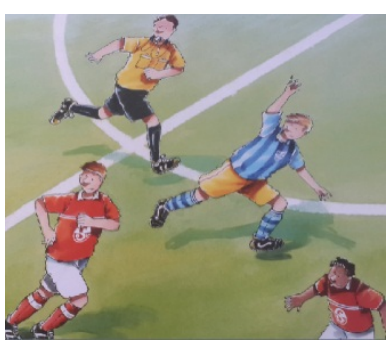

Picture 1. K5

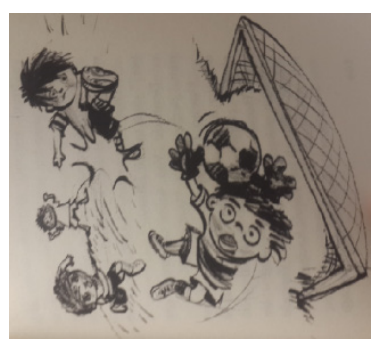

Picture 2. K1
$\mathrm{K} 5$ and $\mathrm{K} 1$ are pictures depicting scenes from the sports branch with the greatest diversity. These pictures are visuals from the books "Arkadaşım profesyonel futbolcu" (My friend is a professional footballer) and "Sihirli top" (Magic ball). While $\mathrm{K} 5$ is depicting a scene from a football match, K1 depicts a scene from a practice session. In K5, the referee of the competition and players of two teams are seen. K1 shows a goal scored during a practice session. Here, players of two teams and the goalkeeper are the elements of the branch of football. The pictures belonging to another sports branch, cycling, are shown below.

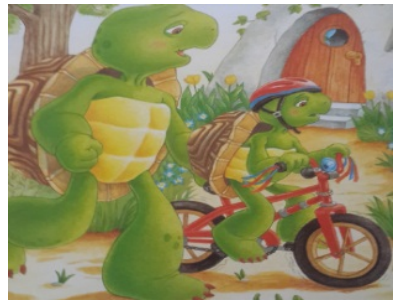

Picture 3. K8

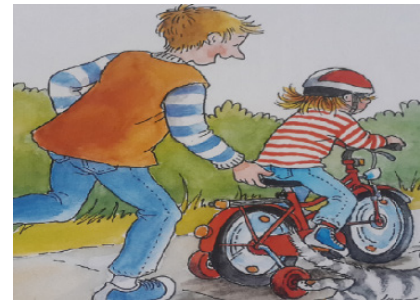

Picture 4. K6 
$\mathrm{K} 8$ and $\mathrm{K} 6$ are pictures depicting scenes from one of the sports branches; cycling, with the greatest diversity. While there is a human figure riding a bike in $\mathrm{K} 8$, there is a figure of a turtle in K6. The figures in both of the pictures are trying to learn riding a bike. A message given in the explanations of the pictures is directed to encouraging the use of crash helmet as a precaution against any accident. Moreover, in both of these pictures, parents are presented as figures supporting their children in their endeavor. The importance of practice in mastering a skill is also emphasized. Only one of the 30 books analyzed was written by a Turkish writer and the sports of yoga is addressed in this book. Emphasizing that mental and physical health is fostered by yoga, the book describes yoga movements by likening them to natural events.

Each of these picture books depicts technical information and skills specific to the sports branch they addressing and informs the reader about the related branch. Picture 5 depicts a figure in the candle pose. The sports branches and the elements specific to these branches found in the children's picture books are given below. The findings related to the football branch depicted in the children's picture books are presented in Table 5.

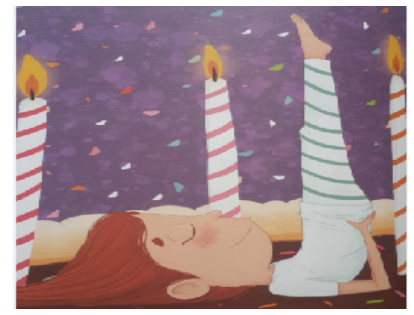

Picture 5. K9

Table 5. Sports Elements Specific to the Football Branch in the Children's Picture Books

\begin{tabular}{|c|c|c|c|c|c|}
\hline Concept & Concept & Material & Sport Environment & & der \\
\hline Sports fan & Forward & Bike & Stadium & Hero & Writer \\
\hline Training & Free shot & Ball & Turf football field & Man & Man \\
\hline Midfield player & Exercise & Crampons & Tribune & Man & Man \\
\hline Players' bench & Warm-up exercises & Catching gloves & & Man & Man \\
\hline $2^{\text {nd }}$ League & Assistant coach & Scarf/flag & & Woman & Man \\
\hline Physical therapist & Woman football player & Vuvuzela & & Woman & Woman \\
\hline Speed & Work-out & Referee's whistle & & Man & Man \\
\hline Strength & Dribbling & Sports bag & & & \\
\hline Endurance & Header & Goalkeeper uniform & & & \\
\hline Lower league & Sports fan & Yellow/red card & & & \\
\hline Muscle relaxation & Foul & Goal & & & \\
\hline Match & Lineman & Shin pads & & & \\
\hline PAF team & Referee & Football socks & & & \\
\hline Equipment & Defender & Pin & & & \\
\hline Rival & Forward player & Cup & & & \\
\hline Coach & Players' bench & Uniform & & & \\
\hline Dressing room & Technique /tactics & & & & \\
\hline Attack & Draw & & & & \\
\hline Marking & Score & & & & \\
\hline Passing area & Goal keeper & & & & \\
\hline Junior category & Barrage & & & & \\
\hline Senior category & Professional player & & & & \\
\hline Penalty area & Midfield & & & & \\
\hline Penalty & Away & & & & \\
\hline Striker & Rule & & & & \\
\hline Press & Substitute & & & & \\
\hline Club chairman & Champion & & & & \\
\hline Captain & Win & & & & \\
\hline Foul & Goal net & & & & \\
\hline Shot & Defense & & & & \\
\hline Push kick/ outside kick/instep kick & & & & & \\
\hline
\end{tabular}

The children's picture books about football: Sihirli top (Magic ball), Arkadaşım profesyonel futbolcu (My friend is a professional footballer), Spor yapıyoruz (We are doing sports), Arkadaşım futbolcu (My friend is a footballer), Elif futbol oynuyor (Elif is playing football), Çağlar Dünya şampiyonu (Çăglar is a world champion) 
In Table 5, football-specific concepts, materials, sports environment, hero and writer of the book are given. Many football-specific concepts are given in the books "Arkadaşım profesyonel futbolcu (My friend is a professional footballer)" and "Sihirli top (Magic ball)". These concepts refer to people involved in football (referee, player, goalkeeper etc.), elements belonging to this sports branch (dribbling, header, barrage, marking, attack, free shot etc.) and coordinative feature of the sports branch (speed, strength, endurance etc.). In both of the books about the football branch, materials used during a football match are given. Moreover, as the environment where football is played, the books mentioned stadium and turf football field. The heroes and writers of the two books about football are men. Findings about another sports branch, athletics, found in the children's picture books are given in Table 6 below.

As can be seen in Table 6, in the picture book with the

theme of athletics, the concepts such as Olympics, race, running, hurdle race, throwing events, Frisbee throwing, throwing an arrow to the target and team slogan. As the environment of athletic events, the book mentioned the athletic field. Many branches of athletics are mentioned in the books including throwing events, jumping and running. Some sample elements of the athletics are shown in the pictures below.

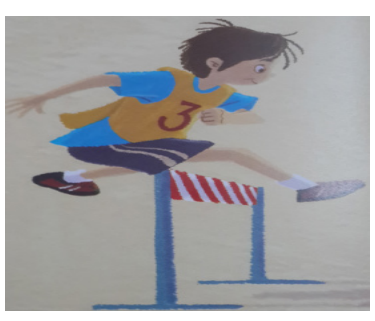

Picture 6. K11

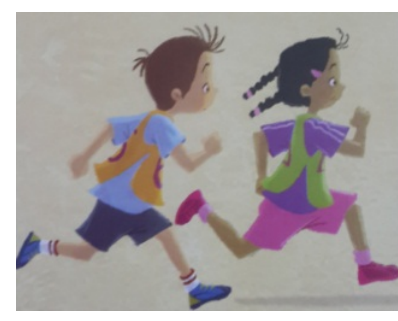

Picture 7. K11

Table 6. Sports Elements Specific to the Athletics Branch in the Children's Picture Books

\begin{tabular}{|c|c|c|c|c|}
\hline \multirow{2}{*}{$\begin{array}{l}\text { Concept } \\
\text { Olympics }\end{array}$} & \multirow{2}{*}{$\begin{array}{l}\text { Materials } \\
\text { Hurdle }\end{array}$} & \multirow{2}{*}{$\begin{array}{l}\text { Sports Environment } \\
\text { Athletic field }\end{array}$} & \multicolumn{2}{|c|}{ Gender } \\
\hline & & & Hero & Writer \\
\hline Race & Arrow & & Woman & Woman \\
\hline Running & Bow & & & \\
\hline Hurdle race & Frisbee & & & \\
\hline Throwing events & Referee's whistle & & & \\
\hline Frisbee throwing & Uniform & & & \\
\hline Throwing an arrow to the target & Trainers & & & \\
\hline $\begin{array}{l}\text { Team slogan } \\
\text { (I can do it, you can do it, we can do it) }\end{array}$ & Target board & & & \\
\hline \multicolumn{5}{|l|}{ High jump } \\
\hline \multicolumn{5}{|l|}{ Practice } \\
\hline Determination & & & & \\
\hline
\end{tabular}

Table 7. Sports Elements Specific to the Cycling Branch in the Children's Picture Books

\begin{tabular}{|c|c|c|c|c|}
\hline \multirow{2}{*}{$\begin{array}{l}\text { Concept } \\
\text { Braking }\end{array}$} & \multirow{2}{*}{$\begin{array}{l}\text { Materials } \\
\text { Bicycle }\end{array}$} & \multirow{2}{*}{$\begin{array}{l}\text { Sports Environment } \\
\text { Playground }\end{array}$} & \multicolumn{2}{|c|}{ Gender } \\
\hline & & & Hero & Writer \\
\hline Steady pace & Tricycle & Garden & Woman & Woman \\
\hline Pedaling & Crash helmet & & Man & Woman \\
\hline Giving signal & Handbrake & & Man & Woman \\
\hline \multirow[t]{9}{*}{ Blowing the horn } & Pedal & & Man & Man \\
\hline & Pin & & & \\
\hline & Handlebar & & & \\
\hline & Saddle & & & \\
\hline & Protective bandage & & & \\
\hline & Wheel & & & \\
\hline & Balance bike & & & \\
\hline & Bicycle pump & & & \\
\hline & Mudguard & & & \\
\hline
\end{tabular}

The children' picture books about cycling: Elif bisiklete binmeyi ögreniyor (Elif is learning riding), Spor yapıyoruz (We are doing sports), Arkadaşım psofesyonel futbolcu (My friend is a professional footballer), Çağlar bisiklet sürmeyi ögreniyor (Çağlar is learning riding) 
In Table 7, elements related to the branch of cycling are presented. In the books, concepts such as braking, steady pace, pedaling, giving signals, blowing the horn are mentioned. The materials mentioned as necessary for cycling are bicycle, tricycle, crash helmet, handbrake, pedal and handlebar etc. This sports branch is presented as an activity that is done in a playground or garden. While both the hero and the writer of the book "Elif is learning riding (K8)" are women, the hero of the book "Franklin is riding a bike (K6)" is a woman; yet, its writer is a man. The visual related to the branch of cycling is given below.

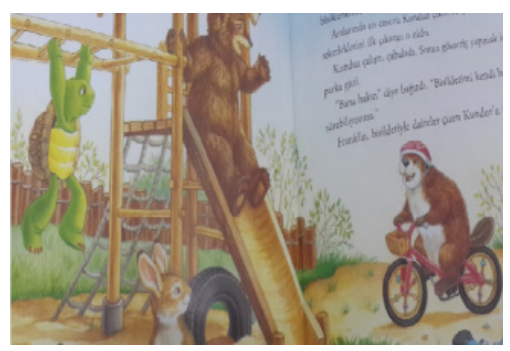

Picture 8. K6

In Table 8, there are some elements related to the branch of ballet. The ballet-related concepts depicted in books through expressions and visuals are ballerina, dancing, stretching exercises, point movement, swaying, floating etc. The materials mentioned as necessary for this sports branch are ballet clothes, ballet shoes, tutu, and swimsuit. Through expressions and visuals, it is indicated that ballet can be performed in a ballet saloon, a ballet school and on a stage. While the heroes of two books are women, their writers are from different genders. A visual from the book "Wriggly (K4)" is given below.

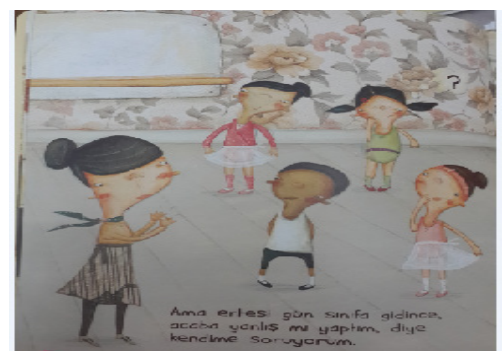

Picture 9. K4

In Table 9, the elements related to swimming depicted in the children's picture books are given. The swimming-related concepts mentioned in the books are pike, breast stroke, diving into water, swimming instructor etc. The materials mentioned as necessary for this branch of sports are diving board, slippers, swimsuit, swim ring, flippers, arm bands etc. As the environment where swimming can be performed, expressions and visuals related to the swimming pool are included in the books. The hero and the writer of the book "İnci is very brave (K7)" are women. The sports elements related to the basketball in the picture book "I can do it" are presented in Table 10.

Table 8. Sports Elements Specific to the Ballet Branch in the Children's Picture Books

\begin{tabular}{llllr}
\hline Concept & Materials & Sports Environment & & Gender \\
\hline Ballerina & Ballet clothes & Ballet school & Hero & Writer \\
\hline Standing on one foot & Ballet shoes & Ballet saloon & Woman & Man \\
\hline Standing and rising on toes & Tutu & Stage & Woman & Woman \\
\hline Dancing & Swimsuit & Dance school & Woman & Man \\
\hline Leading ballerina & Iron bar & & & \\
\hline Stretching exercises & Ballet slippers & & & \\
\hline Ballet instructor & & & & \\
\hline Point movement & & & & \\
\hline Rhythm/music & & & & \\
\hline Stepping & & & & \\
\hline Dancer & & & \\
\hline Movement & & & \\
\hline Swaying & & & \\
\hline Being flexible & & & \\
\hline Floating & & & \\
\hline
\end{tabular}

The children's picture books offering information about Ballet: Ayşsegül bale yapıyor (Ayşegül is doing ballet), Spor yaplyoruz (We are doing sports), Kipır kıpır (Wriggly), Arkadaşım balerin (My friend is a ballerina)). 
Table 9. Sports Elements Specific to Swimming in the Children's Picture Books

\begin{tabular}{|c|c|c|c|c|}
\hline \multirow{2}{*}{$\begin{array}{l}\text { Concept } \\
\text { Fear of swimming }\end{array}$} & \multirow{2}{*}{$\begin{array}{l}\text { Materials } \\
\text { Diving board }\end{array}$} & \multirow{2}{*}{$\begin{array}{l}\text { Sports Environment } \\
\text { Swimming pool }\end{array}$} & \multicolumn{2}{|c|}{ Gender } \\
\hline & & & Hero & Writer \\
\hline Pike & Slippers & & Woman & Woman \\
\hline Swimming instructor & Swimsuit & & Man & Woman \\
\hline Dressing room & Swimming noodles & & Woman & Woman \\
\hline Breast stroke & Swim ring & & Man & Woman \\
\hline Diving into water & Spring board & & Woman & Man \\
\hline Jumping & Swimming circle & & Woman & Woman \\
\hline \multirow[t]{7}{*}{ Swimming course } & Towel & & Woman & Woman \\
\hline & Shower & & & \\
\hline & Water ball & & & \\
\hline & Flippers & & & \\
\hline & Arm bands & & & \\
\hline & Sports bag & & & \\
\hline & Kickboard & & & \\
\hline
\end{tabular}

The children's picture books giving information about swimming: Inci çok cesur (Inci is very brave), Spor yaplyoruz (We are doing sports), Franklin bisiklete biniyor (Franklin is riding a bike), Elif yüzme öğreniyor (Elif is learning swimming), Ayssegül yüzme öğreniyor (Ayșegül is learning swimming), Ayșegül denizin tadını çıkartıyor (Ayşegül is enjoying the sea), Maisy yüzme ögreniyor (Maisy is learning swimming).

Table 10. Sports Elements Specific to Basketball in the Children's Picture Books

\begin{tabular}{lllrr}
\hline Concept & Materials & Sports Environment & & Gender \\
\hline Strengthening arm muscles & Basket ball & Basketball court & Hero & Writer \\
\hline Rules of the game & Basket & & Male & Female \\
\hline Dribbling & Cone & & \\
\hline Throwing a shot & Uniform & & \\
\hline Scoring & Trainers & & \\
\hline Basketball team & & & \\
\hline
\end{tabular}

The children's pictures books: Yapabilirim (I can do it)

In Table 10, elements related to basketball are shown. The concepts mentioned in the book related to basketball are strengthening arms, rules of the game, dribbling, throwing a shot etc. As the basketball-related materials, basketball and basket, cone, uniform and trainers are mentioned in the book. Basketball is presented as a physical activity performed in a basketball court or garden. While the hero of the book is man, its writer is a woman. The visual related to this branch from the book is given below.

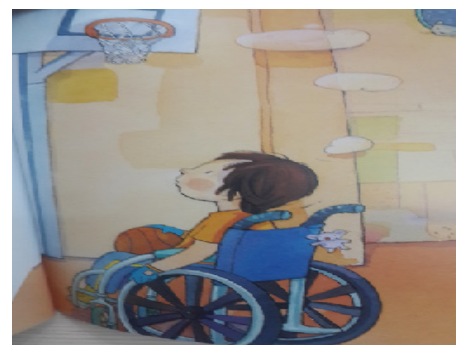

Picture 10. K10

In picture K10, there is a basketball and a basket. In the book giving information about basketball with the slogan "I can do it" presents basketball-related concepts, techniques and materials. Findings related to another sports branch; horse rising, are shown in Table 11.

In Table 11, elements related to the branch of riding addressed in the children's picture books are presented. The riding-related concepts found in the children's picture books are horse trainer, thoroughbred horse, horse dressing, galloping, club, race, barrier etc. As the riding-related materials, saddle, horse, hay, pony, hooves, headgear and skewback are mentioned. In the books, as the riding environments, stable, hippodrome and tribune are mentioned. While the hero of the book is a woman, the writer is a man. The visual found in the books related to this branch is presented below.

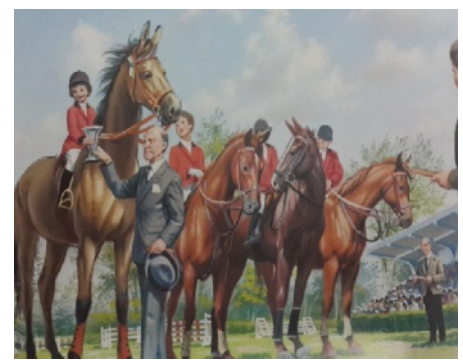

Picture 11. K2 
Table 11. Sports Elements Specific to Horse Riding in the Children's Picture Books

\begin{tabular}{llllr}
\hline Concepts & Materials & Sports Environment & & Gender \\
\hline Horse trainer & Saddle & Stable & Hero & Writer \\
\hline Thoroughbred horse & Horse & Hippodrome & Woman & Man \\
\hline Training & Hay & Tribune & Woman & Female \\
\hline A mare/ Foal & Pony & & Woman & Female \\
\hline Spectators & Hooves & & & \\
\hline Horse dressing & Headgear & & & \\
\hline Rider & Skewback & & & \\
\hline Galloping & & & & \\
\hline Club & & & & \\
\hline Grooming & & & & \\
\hline Race & & & & \\
\hline Rival & & & & \\
\hline Barrier & & & & \\
\hline Cup & & & & \\
\hline Show jumping & & & & \\
\hline
\end{tabular}

The children's picture books giving information about riding: Ayşegül ata biniyor (Ayşegül is riding a horse), Spor yaplyoruz (We are doing sports), Elif ata binmeyi ögreniyor (Elif is learning riding a horse), Elif ve en sevdiği midilli (Elif and her favorite pony)

Table 12. Sports Elements Specific to Yoga in the Children's Picture Books

\begin{tabular}{|c|c|c|c|c|}
\hline \multirow{2}{*}{$\begin{array}{l}\text { Concept } \\
\text { Candle position }\end{array}$} & \multirow{2}{*}{$\begin{array}{l}\text { Materials } \\
\text { Sportswear }\end{array}$} & \multirow{2}{*}{$\begin{array}{l}\text { Sports environment } \\
\text { House }\end{array}$} & \multicolumn{2}{|c|}{ Gender } \\
\hline & & & Hero & Writer \\
\hline Anatomic position & Bandana & Garden & Woman & Woman \\
\hline Strong legs & Hair clip & Forest & & \\
\hline \multicolumn{5}{|l|}{ Arms over the head } \\
\hline \multicolumn{5}{|l|}{ Standing on one foot } \\
\hline \multicolumn{5}{|l|}{ Lying face down } \\
\hline Upper body parallel to the ground & & & & \\
\hline
\end{tabular}

The children's picture books including the branch of yoga: Yogayl seviyorum (I love yoga)

Table 13. Sports Elements Specific to Skiing in the Children's Picture Books

\begin{tabular}{llllr}
\hline Concept & Materials & Sports Environment & & Gender \\
\hline Arcing & Skiwear & Ski resort & Hero & Writer \\
\hline Using chair lift & Ski gloves & Ski school & Man & Woman \\
\hline Ski course & Goggles & & Woman & Woman \\
\hline Ski instructor & Cap & Woman & Man \\
\hline Braking & Ski boots & & & \\
\hline Skiing & Ski pole & & & \\
\hline Race & Sledge & & & \\
\hline Ski license & Ski gear & & & \\
\hline Reward & Medallion & & & \\
\hline
\end{tabular}

The children's picture books including the branch of skiing: Spor yaplyoruz (We are doing sports), Elif kayak yapmayı ögreniyor (Elif is learning skiing), Ayşegül kayak yapıyor (Ayşegül is skiing) 
In Table 12, yoga-related elements found in the children's picture books are given. The yoga-related concepts found in the books are candle position, anatomic position, strong legs, arms over the head, standing on one foot, lying face down etc. As the materials, limited number of elements related to this branch is given in the books; these are sportswear, bandana and hair clip. As the environment where yoga can be performed, house, garden and forest are given. Both the hero and the writer of the book are a man.

In children's picture books, besides heroes, supporting characters are also important. Findings related to depiction of the people found in sports environments in the current study are given in Table 14.

Table 14. Distribution of the People Found in the Sports Environment in the Children's Picture Books

\begin{tabular}{lll}
\hline \multicolumn{2}{l}{ People Found in the Sports Environment } \\
\hline Coach & Footballer & Athlete \\
\hline Ballerina & Goalkeeper & Teammates \\
\hline Parents & Paramedics & Referee \\
\hline Fans & Swimming instructor & Ballet instructor \\
\hline
\end{tabular}

In Table 14, findings related to the people found in sports environments are given. In the book dealing with the branch of football, figures such as referee, footballer and goalkeeper are mentioned. In relation to the branches of riding and athletics, fans are mentioned. In relation to the branches of swimming, ballet, football and athletics, coach, paramedics and parents are mentioned. In learning to play basketball and riding a bike, the support of parents is strongly emphasized and the importance of practice in mastering related skills is also emphasized. Sample visuals related to people found in sports environments are given below.

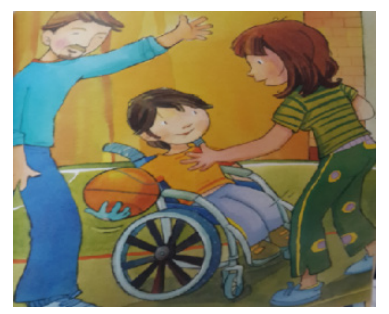

Figure 12. K10

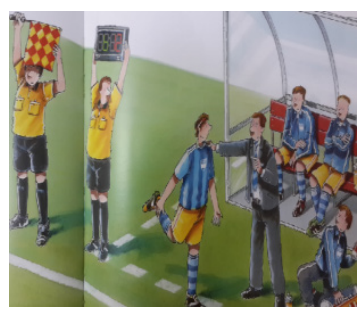

Figure 13. K5
Among the supporting characters, parents and coaches are also frequently mentioned. It was also revealed that particularly the children aged 6 think that sport is done by the weak or the strong. Findings related to "sports-specific values"; one of the sports elements found in the children's picture books are shown in Table 15.

Table 15. Sports-specific Values Found in the Children's Picture Books

\begin{tabular}{ll}
\hline Values & $\%$ \\
\hline Benevolence & 40 \\
\hline Sportmanship & 20 \\
\hline Competing fairly & 20 \\
\hline Putting up with winning and losing & 20 \\
\hline
\end{tabular}

In Table 15, sports-specific values are shown. In the books, benevolence is frequently emphasized, followed by obeying the rules and competing fairly. While benevolence is widely mentioned within the branch of cycling, within the context of the branch of football where the pleasure of winning and frustration of losing can be frequently experienced, the values of obeying the rules and competing fairly are emphasized. Some statements related to these values mentioned in the book K6 are presented below

"...In such cases, free kick is performed. But in general the match is played fairly and kindly (K6)".

"...It is forbidden to touch the goalkeeper in this area. Otherwise, the player is shown a yellow card. The yellow card means warning. The player who violates the rules is sometimes punished with a red card and has to leave the field (K6)"'.

\section{Discussion}

Inclusion of sports elements in children's literature is important for children to gain awareness of sports. In the current study conducted to determine the sports elements depicted in the children's picture books for 3-6 year olds, a total of 30 books with the theme of sports were analyzed. Books were printed by different publishing houses. This might indicate that publishing houses support the publication of certain types of books. "Türkiye İş Bankası" and "Yap1 Kredi" Publishing Houses seem to attach more importance to children's picture books. Türkiye İş Bankası Publishing House has made important contributions to the translation of classics into Turkish. Given that 29 of the children's picture books with the theme of sports are translations to Turkish, it can be argued that this publishing house is of the opinion that translation of foreign children's literature to Turkish will make contributions to the development of children. Of the children's picture books included in the study group of the current research, 16 were published by Türkiye İş Bankası and 7 were published by Yap1 Kredi Publishing Houses; thus, it can be argued that these two publishing houses attach great importance to children's literature. Only two of the books investigated in the current study is in Turkish, which is the book "I love yoga" and "Magic ball". This shows the gap in the children's picture books addressing the issue of sports. Thus, writers writing children's books should focus on creation of books addressing different developmental characteristics of children. Illustrated children's books were determined to press in countries such as Germany, England, Spain and Turkey. The majority of the books were published in Germany $\mathrm{f}$ (20).

In the children's picture books included in the current study, it was found that different sports branches are addressed. While football ( $\mathrm{f}=6)$, cycling $(\mathrm{f}=6)$, swimming $(\mathrm{f}=7)$, horse riding $(\mathrm{f}=4)$, ballet $(\mathrm{f}=3)$ and yoga $(2)$ have been addressed by different books, skiing, basketball, baseball, archery and athletics each have been addressed in only one book. It is thought that mentioned sport branches are appropriate for children's sport understanding.Children 
mentioned sports as an activity which is done in outdoor and fresh air (Yüksek Usta \& Tezel Şahin; 2016). So, it can be said that it is appropriate to use these brances in books are very appropriate for children. Football as a branch of sports has been addressed in children's picture books in a detailed manner. As football is highly popular in today's world, it appeals to different tastes, it allows people to have a good time and enjoy them, and it is found to be a more interesting theme. People's interest in football may make them forget even the most important political and economic problems. The main reason behind this interest is neither aesthetic pleasure as in arts nor health, wellness and physical training as in sports, rather to have a good time and fun. In a study conducted by Y1lmaz \& Güven (2015) [14] on gifted children, it was found that the children frequently depicted football in their drawings as it appears frequently as a product of the popular culture. Besides football, different branches of sports have been addressed in the children's picture books included in the current study. This can be claimed to contribute to the introduction of children to different branches of sports at early ages. A large space is allocated to cycling and swimming sports in the children's picture books. In the literature, there are studies reporting similar findings. Y1lmaz et al. (2017) [22] conducted a study on 3-6 year olds to explore their perceptions of sports and found that the children included similar sports elements in their drawings. In another study investigating children's perceptions of sports, Yüksek Usta \& Tezel Şahin (2016) [23] found that $21.28 \%$ of the children included football in their drawings, $17.02 \%$ running and $12.77 \%$ swimming and gymnastics. In the same study, the children also included some elements from the branches of basketball, weightlifting, tennis, plates, archery, karate, ice hockey, skiing and volleyball in their drawings. In a study done by Tezel Şahin \& Yüksek Usta (2016) [9] to determine pre-school children's perceptions of sports and sports branches, it was found that the participating children prefer running, football, ice skating, weightlifting, fencing, bowling, baseball, and basketball. Aydoğan, Özyürek \& Gültekin Akduman (2015) [13] found that in general the sports branches the children want to be engaged in are football, skating and gymnastics. Huck, Hefler, Hickman and Kiefer (2001) [24], reported that particularly the books addressing the sports branches that can be performed individually or in groups such as tennis, running, gymnastics, skiing, swimming, football and basketball enhance and enrich the children's sports-related experiences. In a study in which Veziroğlu \& Gönen (2012) [12] investigated the compliance between children's picture books and the objectives of the pre-school curriculums developed by the Ministry of National Education, it was found that among 250 children's picture books making up the sampling of the study is there only one book focusing on swimming as a branch of sports. In these books, it is usually aimed to inform the reader about cycling, dribbling, jumping, jumping down from a particular height, climbing, throwing or carrying an object. Though these are skills related to psychomotor capacity, they are not enough to meet the objectives set in the curriculums. Reinforcement of psychomotor development through children's picture books is also closely associated with how books are used. However, it was found that there is a great diversity of sports branches depicted in the children's picture books examined in the current study. There is also diversity of research focusing on children's cognitive structures specific to sports branches. It is can be think that there are two important reasons for why these branches are common in childre's picture book. Firstly, swimming is so common activity in Turkey since the climate and nature of Turkey. Secondly, cycling is a cheap and common activity for many children to reach for many children. So, it is thought that authors can prefer to use swimming and cycling as theme in books.

Wide variety of materials belonging to different sports branches are also presented in the children's picture books. The book "My friend is a professional footballer" published in 2014 by Türkiye İş Bankası Publishing House gives both theoretical and tactical information through words and pictures to the reader. For instance, the reader is informed about the situations in which players can be punished with a yellow or red card, about the importance of obeying the rules of the game for the well-being of players and for the pleasure of watching the game, about how should be prepared for a match and about what kinds of exercises can be done to develop the desired part(s) of the body. When the materials and concepts related to different branches of sports in the books were examined, it was found that the greatest diversity is in football. Materials defined through words are also supported with visuals to increase the retention. Ceylan et al. (2016) [25] investigated mentally retarded children' perceptions of the sports environment and found that the children frequently $(\mathrm{f}=83)$ included sports or activity-related materials in their drawings. These children were particularly found to be good at indicating colors, numbers and shapes of the materials involved in the sports environment in their drawings. In the current study, it was also determined that the children depicted concepts, techniques and materials specific to sports branches in a detailed manner. Inclusion of stimuli targeting more than one sense in children's picture books can be claimed to be affecting children's learning and retention of the knowledge. Within the concepts mentioned in relation to football, the players are presented according to their position in the field such as forward (in the offence), mid-field player and goalkeeper and defender. Moreover, referees are presented as linesmen and referee both verbally and visually. In addition, spectators and coaches are also depicted in the pictures. It is also mentioned that basic motor skills such as speed, strength, endurance and flexibility can be developed in practice sessions. The need for physical therapist for the prevention or rehabilitation of injuries is pointed out. As the materials specific to football, crampons, uniform, socks, shin pads etc. are mentioned. The book "Inci is very brave" dealing with swimming tries to present a wide variety of materials specific to swimming. The materials used while learning swimming such as spring board, swimming noodles, swim ring, diving board, swimming circle, 
flippers, arm bands, kickboard are presented in the book both verbally and visually. As the swimming related concepts, limited numbers of concepts such as pike, breaststroke, diving into water etc. are mentioned. The book "I am ready, I can do it, You can do it, We can do it" gives a lot of information about the sub-branches of athletics. Throwing, jumping and running events are particularly emphasized in the book. The concepts mentioned in the book regarding athletics are throwing events (Frisbee), throwing an arrow to the target, high jump and running events. The explanations of these concepts are reinforced with visuals. In the book, it is also emphasized that in order to prevent possible injuries from occurring, necessary precautions should be taken. For example, while it is mentioning the need for adequate warm up before running to prevent injuries, the importance of using protective bandage and crash helmet while cycling is also emphasized. In the books "Franklin is riding a bike" and "Elif is learning riding a bike)" addressing cycling, the heroes are depicted with their crash helmets on their heads from the beginning to the end of the story. This is a significant stimulus for children. When the books "Ayşegül is doing ballet" and "Wriggly" were examined in terms of concepts and materials, it was seen that not much detail is given about materials and visuals of ballet movements are also included in the books. Inclusion of sports-specific concepts in books is important for children to learn the materials specific to any sports. Such type of information can be beneficial for children to understand and to be aware of that there are rules in every place to obey to make better and fair activity not only sport but also social life.

In the children's picture books, it is depicted that sports can be done in indoor and outdoor areas. In the books, football is depicted in outdoor areas such as turf football field and stadium. Within the context of another branch of sports, athletics, the outdoor areas are emphasized and athletics field is explained both verbally and visually. Cycling, basketball and horse riding are also depicted in outdoor areas. No specific place is described for cycling, yet, as they are secure, playgrounds and gardens are depicted as places to ride. In the pictures where outdoor activities are depicted, green areas and clear air are shown. In a study by Aydoğan, Özyürek \& Gültekin Akduman (2015) [13], it was found that the children responded to the question "Where is sports done?" as generally at home or outside. In a similar manner, Yüksel Usta \& Tezel Şahin (2016) [23] found the participating children heavily emphasized sports branches that can be performed outdoor in their drawings. And generally figures such as sunny weather, clouds, sky, birds, butterflies are shown in the environments where sports is done. The face figures in the picture were found to be generally positive. Sunny and clear weather, light colored clouds and birds drawn together with flowers and trees symbolize happiness and the joy of life (Savaş, 2014) [26]. In light of these findings, it can be argued that the children have positive feelings towards sports. Similar results were reported by Yilmaz et. al. (2017) [22] investigating pre-school children's perceptions of sports environment. In the study, $53.74 \%$ of the children described outdoor places as the environment of sports along with sunny and clear weather and green areas. The existing research has revealed that children need suitable areas to play games involving physical activities (Hamilton, 2002) [27]. In today's world in which possibilities to move are highly restricted, children living in apartment blocks, going to school by school bus and spending most of their time in front of the TV or computer screen have become alienated to play grounds, parks and activities done in these places as a result of urban sprawl as well as this living style.

When the books were examined in terms of their heroes, it was seen that the heroes of the books on football and basketball are men; the writers of the two of the books with the theme of football are men and the writer of the book on basketball is a woman. Majority of the heroes of the books were men while only in one of the books with the theme of ballet, it is a woman and that of the other is a man. Given that the gender of the writer can affect the selection of the hero, the writers and heroes of the books were also examined. Though the writer of one book "Franklin is riding a bike" out of 30 books is a woman, the hero of this was also found to be a man. At the same time, though the writer of the book "Ayşegül is doing ballet" is a man, he selected a women as the hero of his book and while the writer of the book "Wriggly" is a woman, she selected a man as the hero of her book. The male writer addressing horse riding selected a woman as the hero of his book. The book "Ayşegül is riding a horse" focuses on a female figure riding a horse and participating in competitions. In the books addressing the sports of cycling, swimming and basketball, gender is not emphasized. The sport of swimming is depicted as being done by both boys and girls together in the same environment in the book "İnci is very brave". In a text in the book "My friend is a professional footballer", it is stated that there are three girls in the football team. In the book, a professional footballer says that there are some female footballers in the junior team: A: "There are three female players in the team. Woman's football is increasingly drawing more attention. A man player does not have much chance against Aylin". B: I can see. In our team, there is a defense player, her name is Senem; when I play forward I can hardly beat her".

When the books are examined in terms of values, it is seen that while the importance of benevolence is strongly emphasized within the context of bike riding, values such as obeying the rules in football and horse riding and putting up with winning and losing are also pointed out. Moreover, the importance of playing football fairly and honestly and that of sportsmanship is also emphasized. In a study conducted by Yılmaz, Esentürk \& İlhan (2017) [28] to determine middle school students' sportsmanship tendencies in relation to their ethical development, it was found that while they are reading stories when they are confronted with a dilemma including making selection between benevolence and obeying the rules, they seem to generally prefer the act of benevolence. In the same study, in relation to a story focusing on the acts of creating an unfair advantage and honesty/obeying the rules, the 
students stated that they prefer losing to creating unfair advantage by violating the rules to win the match. In the books, in the sections including the environments of sports, sports specific values are brought to the fore. It can be said that using such type of concepts in illustrated child books can be beneficial for children to understand there are some values in life to act better since children can learn many things thanks to books without any press.

\section{Conclusions}

As a result, it can be said that though the sports elements found in children's picture books show diversity in terms of the materials specific to different branches, they do not seem to be enough to broaden children's horizons. The books also present some sports-specific techniques and tactics. It is also pointed out that sports can be done in indoor and outdoor places and the sports branches are generally depicted as being performed in sunny clear weather and green areas. It was found that not enough emphasize is put on sports-specific values in the books; only in three books some sports-specific values in relation to the rules to be obeyed during the completion are mentioned.

\section{Suggestions}

In light of all the data and findings of the current study, it can be argued that due their effect on the child development and awareness, children should be introduced to children's picture books as early as possible. Thus, the following suggestions can be made:

More importance should be attached to the diversity of themes in children's picture books having a considerable impact on child development and more space should be allocated to sports elements in children's books to raise children's awareness of sports as early as possible. In children's picture books, there is a limited amount of information about the values that can be imparted to children in sports environments. More information should be given about these values. Greater priority should be given to relating sports environments presented in children's picture books to actual environments. Only two of the children's picture books examined in the current study was written by Turkish writers. If the elements of Turkish culture are more reflected in children's books, then they can be easier to be implemented by children. If the heroes of children's picture books have different characteristics (physically handicapped etc.), the belief of children having similar characteristics in their doing sports can be increased. Thus, they can be part of the society more easily. While writing their books, writers should not tend to use stereotype heroes. It should be emphasized that all sports branches can be done by all the genders. Through such books, children not having any sports experience can be directed to sports activities and can be encouraged to do sports so that they can lead healthier lives.

\section{REFERENCES}

[1] Heper, E. Sporla İlgili Kavramlar ve Sporun Tarihsel Gelişimi. Spor Bilimlerine Giriş (Ed.: Ertan H), Eskişehir: Anadolu Üniversitesi Yayınları, 2012.

[2] Duman, G. Hareket Eğitimine Giriş. Okul Öncesi Dönemde Beden Eğitimi (Ed.: Duman G), Her Yönüyle Okul Öncesi Eğitim-6, Ankara: Hedef Yayıncılık, 2014.

[3] Çelik, A. \& Şahin, M. Spor ve çocuk gelişimi. International Journal of Social Science, Vol. 6, No.1, 467-478, 2013.

[4] Özyürek, A., Özkan, İ., Begde, Z., Yavuz, N.F. Okulöncesi dönemde beden eğitimi ve spor. International Journal of Science Culture and Sport (INTJSCS), Vol.3, No.3, 479-488, 2015.

[5] Oliver, M., Schofield, GM., Schluter, PJ. Parent influences on preschoolers' objectively assessed physical activity. Journal of Science and Medicine in Sport, Vol.13, 403-409, 2010.

[6] İlhan, E.L. Hareketsiz yaşamlar kültürü ve beraberinde getirdikleri. Milli Prodüktivite Merkezi Verimlilik Dergisi, Vol.3, 195-210, 2010.

[7] Gürten, K. "Harpostum'dan Televizyon Futboluna: Spor, Endüstrileşme ve Hukuk İlişkisi Üzerine", Toplum Bilim Dergisi, Vol.103, 143, 2005.

[8] Bluechhardt, M.H., Shephard, R.I. Using an extracurriculum physical activitiy program to enhance social skills. Journal of Learning Disabilities, Vol. 28, No.3 160-169, 1995.

[9] Tezel Şahin, F., \& Yüksek Usta, S. (2016) Okul Öncesi Dönemde Bir Uygulama Örneği: Spor ve Spor Dalları. International Journal of Science Culture and Sport, 4(3), 200-213.

[10] Özer, D.S., Özer, K. Çocuklarda Motor Gelişim (7.bask1), Ankara: Nobel Yayınları, 2012.

[11] Gönen, M. Okul Öncesi Çağı Çocuğu ve Resimli Kitaplar. Okul Öncesi Eğitimi Dergisi, Vol.16, No.28, 20-21, 1984.

[12] Veziroğlu, M., Gönen, M. Resimli çocuk kitaplarının MEB okul öncesi eğitim programı'ndaki kazanımlara uygunluğunun incelenmesi. Eğitim ve Bilim, Vol.37, No. $163,2012$.

[13] Aydoğan, Y., Özyürek, A., Gültekin Akduman G.. Okul öncesi dönem çocuklarının spora ilişkin görüşlerinin incelenmesi. International Journal of Science Culture and Sport (IntJSCS), Vol.3, 103-115, 2015.

[14] Yılmaz, A., Güven, Ö. Üstün yetenekli öğrencilerin beden eğitimi dersi ve beden eğitimi öğretmeni kavramlarına yönelik algılarının çizme yazma tekniği ile incelenmesi. Journal of Qualitative Research in Education, Vol.3, No.3, $55-77,2015$.

[15] Şimşek, H. Methodical problem in the researches of educational history. Journal of Faculty of Educational Sciences, Vol.42, No.1, 33-51, 2009.

[16] Büyüköztürk, Ş., Çakmak-K1lıç, E., Akgün, Ö. E., Karadeniz, Ş., \& Demirel, F. Bilimsel Araştırma Yöntemleri. Ankara: Pegem, 2009.

[17] Patton, M.Q. Nitel Çalışma ve Değerlendirme Yöntemleri. Ankara: Pegem Yayıncılık, 2014. 
[18] Tavşancıl, E., Aslan, E. İçerik Analizi Ve Uygulama Örnekleri. İstanbul: Epsilon Yayıncılık, 2001.

[19] Yıldırım, A., Şimşek, H. Sosyal Bilimlerde Nitel Araştırma Yöntemleri (8. Baskı). Ankara: Seçkin Yayınları, 2011.

[20] Bailey, K.D. Methods of Social Research. (Fourth Edit.) Free Press, 1982.

[21] Miles, M.B., Huberman, A.M. Qualitative Date Analysis (second edition). United Kingdom: Sage pub, 1994.

[22] Y1lmaz, A., Esentürk, O.K, Pala, Ş., İlhan, E.L. Sports environment perceptions of preschool children. Science, Movement and Health, Vol.17, No.2 247-255, 2017.

[23] Yüksek Usta, S., Tezel Şahin, F. Çocuk Resimlerinde Spor. International Journal of Science Culture and Sport, Vol.4, No.3, 214-227, 2016.

[24] Huck, C. S., Hepler, S., Hickman, J., Kiefer, B., Z. Children's Literature in the Elemantary School. US: The McGraw-Hill Companies, 2001.

[25] Ceylan, D., Topuz, E., Yılmaz, A., Esentürk, O.K., İlhan, E.L. Zihinsel yetersizliği olan çocuklardaki spor ortamı algısı. 3. Uluslarası Spor Bilimleri Turizm ve Rekreasyon Öğrenci Kongresi. 27-29 Mayıs 2016, Gaziantep, Türkiye, 2016.

[26] Savaş İ. Çocuk Resmi ve Bilinçaltı. Yayımlanmamış Yüksek Lisans Tezi. Arel Üniversitesi Sosyal Bilimler Enstitüsü, İstanbul, 2014.

[27] Hamilton, I. Where do children play? Children's Play Information Service Factsheet. http://www.ncb.org.uk/medi a/124830/no.4 where do children play.pdf (Erişim: 05 Şubat 2018), 2002.

[28] Y1lmaz, A., Esentürk, O.K., İlhan, E.L. Ortaokul öğrencilerinin ahlaki gelişimleri açısından sportmenlik yönelimleri. Uluslararası İnsan Bilimleri Dergisi, Vol.14, No.4, 4969-4988, 2017. 